\title{
TER GELEGENHEID VAN HET JUBILEUM VAN HET NEDERLANDS INSTITUUT VAN ACCOUNTANTS
}

Vrijdag 20 Mei en Zaterdag 21 Mei herdenkt het Nederlands Instituut van Accountants de zestigste verjaardag zijner oprichting die op 1 Januari 1895 plaats vond. Het is niet gebruikelijk de zestigste verjaardag als een bijzonder feit te herdenken, doch de vijftigste verjaardag, de gedenkdag waaraan als regel bijzondere aandacht wordt besteed, viel in het tijdperk van het oorlogsgeweld en was hierdoor niet geschikt voor een herdenking die toch gepaard moet gaan met enig ceremonieel en dient te geschieden op een wijze zoals vrije mensen menen dat daarbij past. Vandaar het uitstel van de viering tot op de zestigste verjaardag.

De jubileumviering zal in grote trekken bestaan uit een openingszitting op Vrijdagochtend 20 Mei waarin de Voorzitter van het Instituut een welkomstwoord zal spreken; een jubileumzitting op Vrijdagmiddag $20 \mathrm{Mei}$ waarin $Z_{\mathrm{ijne}}$ Excellentie de Minister van Economische Zaken Prof. Dr J. Zijlstra een kort woord zal spreken en de Heer J. Kraayenhof lid N.I.v.A. een rede zal houden welke tot titel draagt „Het accountantsberoep in Nederland na 60 jaar". Vervolgens houdt het Bestuur receptie waarna 's avonds door het Rotterdams Philharmonisch Orkest onder leiding van Eduard Flipse een jubileumconcert wordt gegeven met de pianist Cor de Groot als solist.

Op Zaterdag 21 Mei zal een accountantsdag worden gehouden waarin Dr H. M. Hirschfeld het onderwerp „Structuurwijziging in de particuliere kapitaalvorming" zal inleiden. Die dag zal worden besloten met een jubileumdiner.

Al deze gebeurtenissen spelen zich af in de grote zaal van het Kurhaus te Scheveningen.

Behalve de Vereniging van academisch gevormde accountants zullen veertien vooraanstaande buitenlandse accountantsverenigingen van hun belangstelling blijk geven door zich te doen vertegenwoordigen.

Voor het Nederlands Instituut van Accountants is deze dag een hoogtijdag. Voor de redacrie van het Maandblad voor Accountancy en Bedrijfshuishoudkunde is het de gelegenheid om aandacht te schenken aan de plaats die het Instituut en zijn leden in het maatschappelijk leven allengs zijn gaan innemen.

Ter gelegenheid van het veertigjarig bestaan deed het Instituut een gedenkboek verschijnen waarin de toenmalige Minister van Economische Zaken, Zijne Excellentie Mr M. P. L. Steenberghe schreef:

„Het Nederlandsch Instituut van Accountants, de oudste organisatie van accountants in Nederland, kan met voldoening terugzien op een periode van grote werkzaamheid, waarin het accountantsberoep mede door de arbeid van het Nederlandsch Instituut in steeds ruimer kringen de erkenning heeft gevonden, welke het verdient. De betekenis van een goed accountantswezen kan niet licht worden overschat. In het uiterst gecompliceerde hedendaagse zakenleven vormen de contrōle en de adviezen van den accountant een factor van opbouwende critiek, welke minder dan ooit zou kunnen worden gemist. En nu de grenzen van de economische bemoeiing door den Staat noodgedwongen zich zoo hebben verlegd, heeft ook 
de Overheid, meer dan vroeger het geval was, de gelegenheid zelf de heilzame werking van een goed accountantswezen te ondervinden.

Daarom wensch ik het Nederlandsch Instituut van Accountants bij zijn veertigjarig bestaan hartelijk geluk en spreek den wensch uit, dat het aan het Nederlandsch Instituut gegeven moge zijn, nog lang zijn waardevollen invloed uit te oefenen op den Nederlandschen accountantsstand in het belang van een gezonde samenleving."

Wij menen dat deze vóór twintig jaren geschreven woorden ook thans nog geschreven zouden kunnen worden. $Z_{i j}$ zouden er op duiden dat niettegenstaande de steeds ingewikkelder complicaties van het hedendaagse zakenleven en de groeiende omvang van de economische bemoeiing van de Staat de Nederlandse accountants in deze twintig jaren er in geslaagd zijn het accountantswezen verder te ontwikkelen tot het peil dat nodig is om aan de steeds zwaarder wordende taak het hoofd te bieden. Dat het Nederlands Instituut van Accountants op deze ontwikkeling zijn stempel heeft gedrukt is zonder twijfel. Steeds nauw voeling houdende met de eisen die het maatschappelijk verkeer aan een goede accountantsstand meent te moeten stellen, toezicht houdende op de gedragingen zijner leden zowel ter voorkoming van handelingen die schadelijk kunnen zijn voor het aanzien van de stand als ter voorkoming van vaktechnische onjuiste gedragingen, richting gevend aan noodzakelijke aanpassing aan gewijzigde inzichten op het gebied van de beroepsuitoefening, is het er in geslaagd de grootste en voornaamste vereniging op het gebied der accountancy te blijven. Dat daarbij de grondigheid van de opleiding tot accountant en de hoge eisen welke aan de verwerving van het lidmaatschap bij de examens worden gesteld een belangrijke rol hebben gespeeld is onmiskenbaar.

Men moet respect hebben voor de omvangrijke arbeid welke door de leden van het Nederlands Instituut van Accountants ten behoeve van de organisatie en de ontwikkeling van het accountantswezen in Nederland geheel belangeloos wordt gepresteerd.

Buiten het Bestuur, ondersteund door verschillende Bestuurscommissies, werken ter bereiking van het doel van het Instituut, het Bureau der examens, de Raden van Tucht en van Beroep en de Kamer voor geschillen benevens de plaatselijke Kringen en correspondenten.

Om enig inzicht te geven in de aard en de omvang van de arbeid die verricht moet worden, volgen hieronder enige inlichtingen geput uit het jaarverslag 1953/4. In dit verenigingsjaar kwam het Bestuur 24 maal en het Dagelijks Bestuur 12 maal bijeen. Te zijner ondersteuning waren o.m. de volgende commissies werkzaam:

de commissie ter bestudering van de vraagstukken, welke voor de beoefenaren van het accountantsberoep voortvloeien uit de economische overheidsvoorschriften;

de commissie ter voorlichting van het bestuur omtrent de vraagstukken welke verband houden met een wettelijke regeling van het accountantsberoep;

de commissie tot uniformering van het Reglement van Arbeid en de Ereregelen van het Instituut en de Voorschriften inzake de beroepsuitoefening van de Vereniging van Academisch gevormde accountants;

de commissie voor vraagstukken betreffende de administratieve organisatie;

m a b blz. 191 
de commissie van advies inzake beroepsaangelegenheden. Deze commissie stelde verschillende subcommissies samen van welke subcommissies steeds een van de leden der hoofdcommissie voorzitter is.

De subcommissies waren:

subcommissie ter bestudering van enkele vragen verband houdende met:

1. de taak en de functie van de openbare accountant op het gebied van de toegepaste bedrijfshuishoudkunde;

2. De verhouding van de openbare accountant tot beoefenaren van andere beroepen, zowel voor het geval deze laatsten bij hem in dienstbetrekking zijn, als in de gevallen dat de relatie een ander karakter heeft;

3. het in verkeer brengen door een openbaar accountant van niet door hem gecontroleerde stukken, met name indien hij optreedt als belastingconsulent of boekhoudkundige werkzaamheden verricht.

subcommissie ter bestudering van enkele vragen voortvloeiende uit artikel 3 der Ereregelen.

subcommissie ter bestudering van de vraagstukken, welke in verband met de ondertekening van de jaarrekening voor de accountant voortvloeien uit het bestaan van latente belastingverplichtingen;

subcommissie ter bestudering van het vraagstuk van de afschrijving op onroerend goed bij levensverzekeringmaatschappijen en exploitatiemaatschappijen van onroerende goederen, zulks in verband met de ondertekening van de jaarrekening door de openbare accountant;

subcommissie ter bestudering van de vragen, verband houdende met de verhouding van leden van het Instituut tot buitenlandse in het openbare beroep werkzaam zijnde accountants;

subcommissie ter bestudering van het vraagstuk der gevolgen van het vormen en van het putten uit geheime en stille reserves voor de goedkeuring der jaarrekening.

Deze opsomming laat zien hoe het Nederlands Instituut van accountants actief is in de verzorging van de behoeften van het verkeer aan een goed georganiseerd accountantswezen door telkenmale wanneer een vraagstuk op zijn gebied actueel wordt dit ter bestudering aan een groep zijner leden op te dragen en daarover rapport uit te brengen.

Het bureau der examens organiseert niet alleen de examens in de verschillende leervakken, doch is ook belast met de organisatie van de opleiding. Op zijn werkzaamheden wordt toezicht gehouden door een Curatorium waarvan een deel der leden in buiten het beroep gelegen functies werkzaam is.

Met de opleiding werden afhankelijk van het vak waarin onderwijs gegeven moet worden zowel leden als niet-leden van het Instituut belast. De accountancy werd steeds door leden van het Instituut gedoceerd. De opleiding werd op verschillende plaatsen verspreid over het gehele land gegeven. Het aantal cursisten beweegt zich tussen 750 en 800 .

Wat de opleiding betreft bestaat er een nauwe samenwerking tussen het Nederlands Instituut van Accountants. de Rijksaccountantsdienst en de Koninklijke Militaire Academie, terwijl wat de schriftelijke examens in de accountancy betreft wordt samengewerkt met alle universiteiten en hoge scholen waar de accountancy wordt gedoceerd. 
In het verenigingsjaar 1953/4 werden 914 candidaten geëxamineerd in de voorbereidende vakken zijnde techniek van de handel, voortgezette wiskunde, financiële rekenkunde en levensverzekeringswiskunde, voortgezet boekhouden, statistiek, recht en belastingrecht. 204 candidaten werden geëxamineerd in sociale economie en eveneens 204 candidaten in bedrijfshuishoudkunde. Voor de hoofdvakken inrichtingsleer, contröleleer en de slotexamens bedroeg het aantal candidaten resp. 386, 287 en 108.

Het aantal leden van het Instituut bedroeg per 31 Augustus 1954 1117. Het steeg regelmatig van 774 per medio 1946 af. 55 pct. hunner is in het openbare beroep werkzaam. Een belangrijk deel van de overige leden is in dienstbetrekking bij de Overheid of als intern accountant bij het bedrijfsleven werkzaam. Het aantal assistenten beliep per 31 Augustus 19543063.

Het belang dat in het openbare verkeer aan de werkzaamheden van de leden wordt gehecht kwam tot uitdrukking in een onderzoek naar de werkzaamheid als openbaar accountant van de leden van het Nederlands Instituut van Accountants bij naamloze vennootschappen welker aandelen ter beurze van Amsterdam officieel zijn genoteerd en in welker jaarverslagen van de activiteit van accountants is blijk gegeven. Uit dit onderzoek bleek dat 95.5 pct. van deze vennootschappen van de diensten van Niva-leden en 4.5 pct. van de diensten van andere accountants gebruik maakte.

Moge het Nederlands Instituut van Accountants bij een volgend jubileum tenminste even sterk staan als thans en in staat blijven zijn voor het maatschappelijk verkeer zo vruchtbare arbeid te blijven verrichten. In de bloei van het Instituut zullen zich dan de verdiensten zijner leden weerspiegelen. 